\title{
Teologia da kénosis e relações de gênero: uma perspectiva de leitura
}

\author{
Kenosis's theology and gender relations: \\ a reading perspective
}

\section{Jaci de Fátima Souza Candiotto*}

Pontifícia Universidade Católica do Paraná (PUCPR), Curitiba, PR, Brasil

\section{Resumo}

Este estudo objetiva analisar, a partir de Gianni Vattimo e de outros pensadores, a passagem de uma imagem de "Deus-forte" e racional correspondente à era da metafísica para a percepção niilista e secularizada de um “Deus-fraco” na Modernidade, e como esta última pode ser pertinente para repensar o lugar do cristianismo no mundo atual; em seguida, e para além de Vattimo, se busca identificar não somente na kénosis da encarnação, mas também na da crucificação, uma percepção do divino que responda aos grandes desafios da contemporaneidade, especialmente o da violência como causadora do sofrimento humano; finalmente, se procura repensar o sofrimento das mulheres a partir da kénosis da crucificação e a possibilidade da teologia das relações de gênero de elaborar uma leitura singular da teologia kenótica.

Palavras-chave: Kénosis. Sofrimento. Relações de gênero. Mulheres. Teologia.

*JFSC: Doutora em Teologia, e-mail: jacicandiotto@gmail.com 


\section{Abstract}

This study aims to analyze, from Gianni Vattimo and other thinkers, the passage from an image of a "strong God" and rational corresponding to the era of metaphysics to the nihilistic and secularized perception of a "weak God" in Modernity, and how the latter may be pertinent to rethink the place of Christianity in the present world; then and beyond Vattimo, one seeks to identify not only the kenosis of the incarnation but also that of the crucifixion, a perception of the divine that responds to the great challenges of contemporary times, especially that of violence as the cause of human suffering; finally, we try to rethink the suffering of women from the kenosis of crucifixion and the possibility of the theology of gender relations to elaborate a singular reading of the kenotic theology.

Keywords: Kenosis. Suffering. Gender relations. Women. Theology.

\section{Introdução}

Desde o século XVII, comumente admitido como o limiar da modernidade, enfatizou-se a imagem de um Deus Poderoso, que opera a partir de princípios racionais, de verdades eternas e imutáveis.

O mecanicismo cartesiano postula que o ser humano é sua razão, ao mesmo tempo que ele tem um corpo, entendido somente como organismo que obedece a leis que podem ser conhecidas. A supervalorização da razão humana reforçou a ideia de um Deus racional, calculista, infinito e, por isso, avalista das certezas procedentes da razão humana finita. Como mostra Descartes, é possível compreender a ideia da perfeição divina em mim como uma realidade objetiva, mas não o conteúdo de sua perfeição ${ }^{1}$. Mas essa perfeição é pensada em termos de racionalidade, de conhecimento. É impossível logicamente que um conhecimento finito possa conhecer uma perfeição infinita. Na medida em que a perfeição de Deus é pensada somente por critérios racionais, não levando em consideração a liberdade divina e a gratuidade de sua bondade, os modernos criaram a imagem de um Deus

1 Cf. DESCARTES, 1973, p. 116 , §27. 
"forte" que atua sobre a natureza, assim como a razão humana submete o mundo natural pelo conhecimento de suas leis.

Na verdade, Deus é que foi aprisionado nos limites impostos pela razão mecanicista moderna. Na aurora da modernidade a razão, ao proporcionar segurança, torna-se indissociável do poder, da dominação. O empirismo de Francis Bacon (1561-1626) concebe o saber como guia da ação: "Saber é Poder" ${ }^{2}$ significa que para o alcance do progresso social é fundamental o domínio do homem sobre a natureza. Mas somente é possível dominar a natureza obedecendo-a, conhecendo suas leis.

Se as leis da natureza podem ser decifradas por um processo racional, também a conduta humana, para ser moral, deverá submeter-se a leis que decorrem de um processo racional. No terreno da moralidade, a origem das normas morais cada vez mais é localizada em uma essência humana racional, e cada vez menos nos imperativos divinos. A indesejável heteronomia moral é atribuída a Deus e à intermediação da Igreja por parte do secularismo moderno. Os mandamentos divinos não passariam de fontes heterônomas da moral. Por sua vez, também são heterônomas quaisquer ações que não sejam guiadas pela razão. Os móveis da sensibilidade, tais como os interesses e os desejos, jamais podem ser considerados fundamentos da moralidade. Somente a ação guiada por um processo racional é considerada autônoma ${ }^{3}$. A emancipação, a autonomia e o esclarecimento do ser humano moderno são postulados como inversamente proporcionais à obediência política, à heteronomia moral e à tutela supostamente "obscurantista" da religião ${ }^{4}$.

Essa confiança exagerada na razão e no progresso, seja por parte das ciências, seja no terreno da moralidade, esteve por detrás dos principais ideais modernos de emancipação do sujeito. Estes, por sua vez, supunham desfazer-se dos vínculos de obediência que caracterizavam a reta conduta da época feudal. Aquela confiança também reforçou a diferença entre razão pública e razão privada: liberdade e igualdade no âmbito público; relações de mando e obediência, no âmbito privado. E a religião passou a ser algo do terreno das escolhas privadas.

\footnotetext{
BACON, 1973, p. 19.

Cf. KANT, 1973.

Cf. KANT, 2005.
}

Rev. Pistis Prax., Teol. Pastor., Curitiba, v. 10, n. 2, 434-452, maio/ago. 2018 
Tudo isso propiciou uma relação inversamente proporcional entre a emancipação humana e a obediência a Deus. Afloraram as principais manifestações de ateísmos na modernidade, apontando a correlação entre o distanciamento cada vez maior entre a imagem de um Deus racional, calculista e a percepção moderna da autonomia humana.

Os desdobramentos da mentalidade moderna na racionalização da economia e da política, no desenvolvimento científico e tecnológico, na industrialização e intensificação do consumo também marcaram uma nova relação com o divino. O ser humano descobre que pode transformar a natureza, que esta se assemelha a um livro aberto a ser decifrado e controlado; ele também está convencido de que pode realizar seus projetos e sonhos de felicidade. O progresso das ciências médicas, particularmente da medicina social e preventiva, faz com que os limites humanos relacionados à doença sejam, em certos aspectos, transpostos ou, como no caso da morte, postergados. O conjunto desses fatores aponta para um conceito imanentista de salvação, relacionado à saúde, ao progresso e ao bem-estar socioeconômico. Se o foco da salvação transcendente se perde, Deus deixa de ser tão necessário.

Depois de ter tomado consciência das potencialidades recônditas da própria razão, o ser humano é capaz de solucionar os problemas mais diversos e de encontrar respostas para as questões mais difíceis. Deus tornou-se, de fato, dispensável e até supérfluo. Não se necessita mais de sua constante presença experimentada como graça nem de sua generosa e gratuita providência. A providência divina tornou-se desnecessária, uma vez que praticamente tudo pode ser previsto e planejado pelo ser humano mediante cálculos cada vez mais precisos ${ }^{5}$.

A partir dessas mudanças, os modernos construíram outros referenciais, como a Ciência, a Pátria e o Partido. Para substituir a crença na salvação transcendente eles propuseram religiões de salvação terrestre, especialmente o cientificismo, o patriotismo e o comunismo: não podendo sustentar-se numa ordem cósmica e na providência divina, os modernos inventaram religiões de substituição, espiritualidades sem Deus ou ideologias que, ao professarem recorrentemente um ateísmo radical,

5 FERRY, 2007, p. 167-168. 
agarraram-se, apesar de tudo, a ideais capazes de dar um sentido à existência humana, ou de justificar que se morra por eles ${ }^{6}$.

Se os modernos propuseram uma salvação imanentista pelo eudeusamento da Ciência, da Pátria e do Partido, os contemporâneos, por sua vez, dessacralizaram o Estado-Providência ${ }^{7}$, mostraram os discursos ideológicos que constituem os partidos políticos e denunciaram a fragilidade a que o mau uso da ciência expôs todas as espécies do planeta.

A fragmentação do pensamento e da sensibilidade de nossa era contemporânea em mil pedaços (Mille plateaux, como interpretam Deleuze e Guatarri) ${ }^{8}$ corresponde ao predomínio do "pensamento fraco" (pensiero debole) em contraste com o pensamento "forte" da época moderna. Quem cunhou a expressão "pensamento fraco" para se referir à nossa época e sua relação com uma nova perspectiva de cristianismo é Gianni Vattimo. O contexto da reflexão de Vattimo é a chamada Pós-modernidade, com seus desdobramentos sobre os modos de pensar, de agir e de crer em nossas sociedades.

\section{Fim da metafísica, niilismo e pensiero debole}

Se tomamos como referência seu livro intitulado Depois da cristandade $^{9}$, percebemos que esse escrito é parte de um clima intelectual e prático muito disseminado nas sociedades ocidentais, o qual questiona o fundamento do real pela metafísica clássica, coloca em descrédito os metadiscursos narrativos e a organização total da sociedade pela racionalização do trabalho e, sobretudo, questiona a moral e as verdades religiosas da cristandade. $\mathrm{O}$ autor procura demonstrar que o fim da metafísica (a qual, mais do que uma verdade, é somente uma hipótese heideggeriana

6 FERRY, 2007, p. 75.

7 Também conhecido como Welfare State ou Estado de bem-estar social. Como se sabe, a providência é um conceito teológico. Ele designa a ação divina de prover, de sustentar, de proteger, de intervir positivamente na história humana. A secularização do conceito se refere à ação do Estado de manter o bem-estar da população mediante políticas públicas de distribuição de renda, saúde, educação, emprego e seguridade social. Este modelo de Estado foi teoricamente elaborado por John M. Keynes (1883-1946) e colocado em prática, pela primeira vez, nos anos 1930, no governo americano de Roosevelt, no programa conhecido como New Deal.

8 DELEUZE; GUATARRI, 1980.

9 Utilizamos a tradução francesa (cf. VATTIMO, 2004). 
correspondente à morte do Deus moral nietzcheana) e o pluralismo pós-moderno nos impelem a realizar uma renovação da experiência religiosa (cristã) ${ }^{10}$. Isso ocorre porque o suposto fim da metafísica não é o fim do cristianismo, mas sua realização mais surpreendente.

O fim da metafísica, no entender de Heidegger, significa o crepúsculo da crença em um princípio supremo, um fundamento último da realidade sob a forma de uma estrutura objetivista dada fora do mundo cujo começo é a filosofia platônica (antes ainda, a parmediana) e seus desdobramentos na crença em uma ordem fundada, estável, necessária, objetivamente cognoscível do ser ${ }^{11}$. Ora, o Deus da moral cristã é aquele identificado à verdade; e a verdade como descrição exata e objetivista da "realidade". Essa verdade é o Cristo ${ }^{12}$. Ele é a garantia suprema da ordem do mundo, razão pela qual o fim da metafísica está relacionado ao ocaso da crença na imagem moral de Deus.

Apesar das críticas de Nietzsche ao humanismo moderno, acusando-o de ser a causa da décadence e do niilismo, Vattimo identifica uma relação "positiva", produtiva, entre a vontade de nada, característica do niilismo, e a imagem do Deus bíblico que se esvazia, que se despoja, que se rebaixa de sua condição divina e se faz homem pela encarnação (kénosis). Se, de um lado, o ocaso da metafísica (hipótese heideggeriana) é correspondente ao declínio da imagem do Deus "forte" da moral e da verdade, de outro, a emergência da ontologia existencial permite que o ser se desvele (se abra, se doe) como acontecimento (Ereignis) ${ }^{13}$, como dasein, como ser-aí, o qual concerne à imagem do Deus que se doa, que se esvazia para poder se comunicar e se relacionar com o ser humano.

A relação entre o esvaziamento divino e o niilismo que a filosofia descobre como traço característico da história do ser na Modernidade pressupõe, portanto, que a secularização moderna não é necessariamente o fim da religião, especialmente do cristianismo. É possível que esse processo de secularização somente tenha sido possível a partir do próprio cristianismo. Com efeito, no entender de Max Weber, a secularização se

10 Ibid., p. 15.

11 Heidegger publica sua obra, Sein und Zeit, em 1927. Cf. HEIDEGGER, 2012.

12 VATTIMO, 2004, p. 156.

13 Ibid., p. 41. 
materializou da homogeneização e racionalização que a tecnologia exerce sobre o mundo. Entretanto, essa racionalização (capitalista) do mundo não se baseia na negação do cristianismo, posto que está fundamentada numa espécie de "aplicação" da ética protestante ${ }^{14}$ e, de modo mais genérico, do monoteísmo judaico-cristão ${ }^{15}$. Assim como Weber, Vattimo considera que a modernidade é a era da secularização, ou seja, a época do desenvolvimento "lógico"16 da revelação judaico-cristã.

Nesse sentido, a secularização não deve ser pensada como um fenômeno de abandono do cristianismo, e sim como a realização paradoxal de sua vocação íntima ${ }^{17}$. A partir da secularização é que a experiência do esvaziamento do ser como acontecimento histórico pode ser correlacionada à imagem do enfraquecimento de Deus na história da salvação. Vattimo quer tomar distância de uma interpretação literal da Bíblia e apontar que o texto sagrado é passível de uma leitura exegeticamente legítima e hermeneuticamente adaptada a uma experiência de Deus aberta a uma época avessa ao objetivismo, ao universalismo e ao racionalismo. Ele aponta, nesse sentido, o "esvaziamento" como núcleo central não somente do Novo Testamento, mas também na redenção veterotestamentária. Por certo, a noção bíblica da criação e da contingência, assim como a historicidade de nossa existência tornam possível o pensamento do ser como acontecimento. Isso é mais notável no Novo Testamento, especialmente no acontecimento da kénosis da encarnação de Cristo.

O renascimento do cristianismo não religioso na era Pósmetafísica se explica pelo possível parentesco entre a tradição da kénosis do Cristo e a compreensão do Ser como acontecimento e esvaziamento.

14 Weber se refere principalmente à relação entre a ascese e o espírito do capitalismo. Ainda que pretenda tomar o protestantismo ascético como um todo, aquilo que fundamenta seu conceito chave de "vocação" para sustentar essa relação, está apoiado especialmente no puritanismo inglês, oriundo do calvinismo (Cf. WEBER, 1974, p. 207).

15 No entender de Vattimo, "0 monoteísmo [...] é a condição para pensarmos a natureza sob a perspectiva unitária de uma ciência física, base indispensável para o domínio tecnológico da própria natureza; enquanto a ética cristã, sobretudo protestante, é a condição para concebermos o trabalho, a poupança, o sucesso econômico, como imperativos religiosos e, portanto, capazes de suscitarem um empenho profundo e total" (VATTIMO, 2004, p. 96-97).

16 Ibid., p. 50

17 Ibid., p. 42.

Rev. Pistis Prax., Teol. Pastor., Curitiba, v. 10, n. 2, 434-452, maio/ago. 2018 
Esse parentesco fornece à filosofia, mas também à teologia e às ciências da religião, a base para que sejam analisadas criticamente as formas do ressurgimento do sagrado, principalmente quando elas traem suas aspirações antimetafísicas, no sentido de que tentam impor um fundamentalismo bíblico mais objetivista e fechado que a própria metafísica medieval. Um dos principais efeitos filosóficos da admissibilidade da "morte do Deus metafísico” e sua relação com a teologia da kénosis é, pelo contrário, preparar o terreno para uma possiblidade renovada de experiência religio$\mathrm{sa}^{18}$ não metafísica e não fundamentalista.

Não imagine o leitor que o pensador italiano esteja simplesmente aderindo aos constructos filosóficos de Nietzsche e Heidegger, repetindo assim um percurso bem conhecido do chamado pensamento pós-metafísico. Muito pelo contrário, ele cogita que tanto o niilismo de Nietzsche quanto a ontologia existencial de Heidegger permanecem prisioneiros do objetivismo grego porque essas filosofias recusam desenvolver até o limite as implicações da revolução antimetafísica cristã. Eles não percebem ou não é seu objetivo reconhecer que essa revolução pode ser identificada com a perspectiva aberta pela teologia da kénosis.

A kénosis de Jesus é portanto apresentada por Vattimo não somente como algo compatível com os processos de secularização, mas também como um modelo para esses processos. Um Deus que se esvazia de si mesmo é apresentado como a imagem mais adequada para a sensibilidade cultural de nossa época. A posição de Vattimo tem importância significativa para uma nova percepção a respeito da imagem de Deus compatível com a experiência religiosa atual. Ela envolve deixar de pensá-Lo como um ser violento ou absoluto ao mesmo tempo em que torna o esvaziamento seu atributo fundamental.

Como possibilidade de avaliação crítica da posição de Vattimo ${ }^{19}$, pode-se inferir, em primeiro lugar, que sua ênfase na secularização como principal marca de nossa cultura está defasada. Nos últimos decênios, constatamos um retorno de formas religiosas ou manifestações religiosas em diversas partes do mundo, depois da queda dos símbolos da salvação imanentista, tais como o Muro de Berlim, o socialismo real e a ideia de

18 Ibid., p. 30.

19 Boa parte dessa avaliação está inspirada no artigo de Roldán (2007). 
Nação (esta última, a partir dos processos de globalização econômica nos anos 1990). Nos Estados Unidos, na América Latina, no Leste Europeu, na África e na Ásia, o ressurgimento de um cristianismo religioso é um fenômeno notável que não pode ser desconsiderado. Como afirma Habermas: "Enquanto as sociedades desenvolvidas são cada vez mais seculares, a sociedade mundial é cada vez mais religiosa" ${ }^{20}$. Entretanto, seu diagnóstico é razoável se atentarmos para o fato de que ele sente e escreve a partir da vivência da secularização europeia ocidental, na qual o retorno de um cristianismo religioso jamais ocorreu ${ }^{21}$.

Outro aspecto que merece ser problematizado no pensamento de Vattimo é o lugar a partir do qual o cristianismo pós-moderno é situado, a saber, a derivação do niilismo pelo par nietzschiano-heideggeriano. Consequência desse niilismo é a perda na crença em uma verdade objetiva. Ao elevar o nada a categoria central, essa opção coloca os fiéis em um lugar (ou não lugar) que se afasta do recinto fundamental a partir do qual a fé é fundada: o Deus eterno, como fundamento do Ser. Dito de outra maneira, a ênfase no Deus caridade é muito apropriada à nossa época, mas o fato de que Deus decidiu despojar-se de si mesmo não significa que renunciou à sua condição divina.

Além disso, Vattimo parte do pressuposto da interpretação heideggeriana de Nietzsche consoante a qual vivemos na era do fim da metafísica, porém não da ontologia. Cumpriria estudar melhor se a metafísica, na sua função de dar conta da realidade como um todo, já não tem mais

20 HABERMAS, 2008, p. 6. Conforme Habermas, esse ressurgimento também é "resultado das altas taxas de natalidade dos países mais pobres ou em desenvolvimento. Ainda que, é claro a expansão da religião não possa ser explicada somente em termos de tendências demográficas. Um exame mais cuidadoso dos campos afetados tende a confirmar a hipótese de que existe uma conexão entre insegurança existencial e necessidade religiosa. Por exemplo, diversos grupos vulneráveis na América Latina, Ásia e África são mais receptivos às mensagens dos líderes carismáticos das mega-igrejas evangélicas; de modo que a radicalização fundamentalista e a instrumentalização política das comunidades religiosas podem ser explicadas em termos consistentes com a tese da secularização" (Ibid., p. 6-7).

21 Não é objetivo de nosso estudo se deter nessas novas formas de cristianismo religioso, principalmente na América Latina e no Brasil. Entretanto, haveria que investigar como poderiam ser pensados dois fenômenos religiosos de nossa época: de um lado um cristianismo tradicionalista, ritualístico e avesso, no âmbito católico, ao espírito do Vaticano II e, portanto, postulador de um retorno à metafísica, à imagem objetivista de um Deus forte, racional, Todo-Poderoso. De outro, um cristianismo sentimentalista, emotivista e triunfalista cuja forma neopentecostal se conjuga a um fundamentalismo moral distante da imagem kenótica de Deus.

Rev. Pistis Prax., Teol. Pastor., Curitiba, v. 10, n. 2, 434-452, maio/ago. 2018 
sentido, simplesmente por ela ter sido negada pelos contemporâneos. A constatação parece apontar o contrário. Ainda que o ser humano de nossa época seja adepto do pluralismo e do relativismo, não poderia talvez resistir ao niilismo por muito tempo. Não é incomum, pois, o retorno esporádico a um referencial unívoco para dar sentido à vida e ao mundo. Nesse sentido, o ressurgimento de novas formas de ritualizar o cristianismo religioso, como apontado acima, não refletiria um certo cansaço da crise de fundamentos de nossa época? E eles não se limitariam ao mero retorno ao passado, respondendo a um contexto que já não é o nosso, ou, por outro lado, se restringiriam à predominância do sentimentalismo religioso sem uma reflexão teológica suficiente sobre o real significado do Deus-Amor?

A despeito destas provocações que o pensamento de Vattimo nos proporciona, uma de suas contribuições fundamentais é a de ter salientado que a imagem de Deus mais aceitável diante de uma época marcada pela incerteza, pela angústia e pela desesperança seria a de um "Deus fraco" que, na pessoa de Jesus Cristo, se rebaixou e assumiu o modo de existir humano (encarnação). Nesse sentido, a secularização não demarca o fim do cristianismo, mas a exigência de uma nova maneira de pensá-lo e assumi-lo.

\section{A problemática do sofrimento a partir da kénosis da crucificação}

Para além de Vattimo, é mister pensar a kénosis não somente pelo viés da encarnação, mas também a partir da maneira como Deus, na pessoa de Jesus Cristo, se deixou expulsar da comunidade humana da pior forma possível, qual seja, a crucificação. Essa possibilidade de pensar a kénosis vai ao encontro de uma das maiores experiências do século XX, marcada pelo sofrimento de milhões de inocentes em campos de concentração, com a imperiosa diferença de que foram forçados a morrer não porque eram inimigos ou questionaram a ordem social estabelecida, mas simplesmente porque pertenciam a uma comunidade específica, a uma etnia determinada, a uma origem sanguínea particular.

Entendemos que a compreensão do Deus da verdade, da razão e do progresso, em suma, do Deus forte entra em crise não somente por ocasião dos ateísmos e da secularização da Modernidade e da Pós-modernidade, mas 
também pela intensificação e extensão da experiência do sofrimento. Esse sofrimento foi potencializado pelo Holocausto e seus campos de concentração 22 ; pelo advento da era nuclear e pela angústia diante da possibilidade da dizimação da espécie; pelo crescimento das desigualdades econômicas e sociais e a difícil convivência com a miserabilidade; pelas novas configurações do patriarcado nas sociedades ocidentais, que continuam a oprimir tanto homens quanto mulheres. A dilatação e a pluralidade dessa experiência de sofrimento colocam em crise a ideia de que o progresso rumaria a uma sociedade melhor e mais humana, assim como o poder da razão substituiria, de uma vez por todas, a violência e demais formas de irracionalidades.

Diante da experiência do sofrimento emerge, no âmbito religioso, a imagem e a percepção de um Deus distante que, ao criar o ser humano, deixou-o relegado às arbitrariedades da dominação dos mais fortes sobre os mais vulneráveis. Se no ateísmo e indiferentismo religiosos se vive em um mundo como se Deus não existisse, a experiência do sofrimento muitas vezes é correlata da imaginação de um mundo sem Deus, que não auxilia nem protege aqueles que sofrem; ou ainda, de um Deus impotente que se deixou expulsar do mundo para entregar o ser humano ao seu próprio destino e às injustiças de seus semelhantes.

Essa imagem e percepção de Deus podem ser problematizadas a partir do estudo em torno da kénosis da crucifixão. Como é possível que, na sua onipotência, Deus se deixa expulsar do mundo, morto na cruz? Se, desde os tempos mais remotos, Ele foi invocado como o Todo-poderoso, como pode agora se revelar como um Deus desconcertantemente fraco, que se deixa vencer pela força do ser humano? Outros ainda se perguntam: se Deus é tão misericordioso, por que Ele se retira do mundo para deixar o ser humano entregue às suas próprias forças e ao seu inelutável destino? Por que Deus não intervém para pôr um fim a esta situação de injustiça criada pelo ser humano na sua autonomia e impostura? ${ }^{23}$

22 A esse respeito, podemos indicar o livro clássico de Hanna Arendt, Origens do totalitarismo: Antissemitismo, imperialismo, totalitarismo (2012).

23 TAVARES, 2010, p. 76. 
No entender de Sinivaldo S. Tavares, a resposta a estas indagações encontra sua maior expressão nessa extensa passagem do teólogo protestante, D. Bonhöffer, conhecido como o mártir do nazismo:

E não podemos ser honestos sem reconhecer que temos de viver no mundo - etsi deus non daretur. E reconhecemos justamente isso - perante Deus! Deus mesmo nos obriga a esse reconhecimento. Assim, nossa maioridade nos leva a um reconhecimento mais veraz de nossa situação perante Deus, que nos faz saber que temos de viver como pessoas que dão conta da vida sem Ele. O Deus que faz com que vivamos no mundo sem a hipótese de trabalho é o Deus perante o qual nos encontramos continuamente. Perante e com Deus vivemos sem Deus, que se deixa empurrar para fora do mundo até a cruz. Deus é impotente e fraco no mundo, e exatamente assim, somente assim Ele está conosco e nos ajuda. Em Mt 8, 17 está muito claro que Cristo não ajuda em virtude da sua onipotência, mas da sua fraqueza, do seu sofrimento! Neste ponto reside a diferença decisiva em relação a todas as religiões. A religiosidade do ser humano o remete, na sua necessidade ou aflição, ao poder de Deus no mundo; é o deus ex machina. A Bíblia remete o ser humano à impotência e ao sofrimento de Deus; somente o Deus sofredor pode nos ajudar. Neste sentido, pode-se dizer que o desenvolvimento, acima descrito, que levou à maioridade do mundo, através do qual se acaba com uma concepção errônea de Deus, liberta o olhar para o Deus da Bíblia, que obtém poder e espaço no mundo por meio de sua impotência. Este decerto será o ponto de partida da "interpretação mundana" (grifos nossos) ${ }^{24}$.

No entender de Bonhöeffer, o ser humano emancipado e secularizado de nossa época é incapaz de compreender a interpretação religiosa da teologia e dos conceitos bíblicos. Foi necessária a leitura mundana desses conceitos para que ele fosse purificado da metafísica tradicional e liberado para entender a Revelação pela experiência e linguagem do sofrimento. A morte de Jesus Cristo vem justamente mostrar que vivemos em um mundo caracterizado pelo retiro de Deus. Não quer dizer que devemos pensar Deus sem o mundo. Apesar de ter se deixado expulsar pelos homens, Ele mantém uma relação próxima com o mundo, já que o Deus de Jesus Cristo mostrou que suporta o sofrimento mais insuportável ao ser humano.

24 BONHÖEFFER, 2003, p. 487-488. 
Deixando-se expulsar do mundo e permitindo que o ser humano seja autônomo e, portanto, adulto, Deus faz-se radicalmente presente. Essa afirmação contrasta nitidamente com a típica atitude religiosa de fixar um lugar fora do mundo e acima do ser humano para Deus. Atitude responsável pela teoria metafísica da onipotência divina, de um Deus presente em toda parte e, a rigor, em nenhuma parte ${ }^{25}$. Portanto, a atitude do cristão deve ser a de participar criticamente do sofrimento de Deus no mundo associando-se à experiência kenótica de Jesus.

Na pessoa do crucificado, Deus se revela em sua fraqueza e sofrimento radicais interpelando-nos a nos fazermos solidários com Ele no mundo e a participarmos de sua impotência. Essa exigência envolve a sincera atitude de conversão concebida como autêntica renúncia aos próprios problemas, tribulações, angústias e, até mesmo, à própria condição de pecador para deixar-se assim guiar única e exclusivamente por Jesus Cristo ${ }^{26}$.

A teologia do esvaziamento do Deus crucificado vem mostrar que Ele é solidário ao sofrimento do ser humano. Uma imagem desse sofrimento dá-se pela experiência que nós, mulheres, padecemos na sociedade patriarcal: muitas vezes exploradas no mundo do trabalho pela mão de obra barata e pelo salário desigual para iguais funções e atribuições; no mundo familiar ao modo de objeto da violência doméstica e confinada no domínio privativo e escondido do lar; no mundo cultural pela imposição dos valores masculinos como padrão de conduta e de comportamento. Trata-se da violência cotidiana na qual as mulheres são esvaziadas de si mesmas, não voluntariamente, mas por intensas relações de dominação nas quais valores, comportamentos e atitudes masculinas são normativos para homens e mulheres.

\section{Kénosis e gênero}

Nos itens anteriores delimitamos a necessidade de pensar um cristianismo aberto à era da secularização mediante o privilégio da experiência de fé e da imagem de um Deus-fraco (na linguagem da kénosis

25 TAVARES, 2010, p. 76.

26 Ibid., p. 78.

Rev. Pistis Prax., Teol. Pastor., Curitiba, v. 10, n. 2, 434-452, maio/ago. 2018 
da encarnanção, retomada por Vattimo), assim como um cristianismo atento aos problemas do mundo mediante o recurso à imagem de um Deus-sofredor (na expressão da kénosis da crucificação, priorizada por Bonhöeffer). A partir desse momento, buscamos destacar que esses desdobramentos do Deus-Caritas podem ser considerados os esforços práticos e teóricos mais apropriados para repensar a produção do sofrimento de gênero resultante das relações historicamente complexas entre mulheres e homens na sociedade. Essa indicação parece ser mais efetiva ainda que não exclusiva - se essa reflexão, ao mesmo tempo filosófica e teológica, for feita a partir da experiência das próprias mulheres.

Uma das linhas de reflexão assumida pela teologia feita na perspectiva das mulheres ou, se quisermos, por expoentes da teologia das relações de gênero, é estudar a imagem de Deus a partir da kénosis ${ }^{27}$. Há muitas maneiras de correlacionar kénosis e sofrimento das mulheres. Nesse item queremos avaliar os desdobramentos da kénosis de Jesus Cristo para a luta contra esse sofrimento e opressão. Valemo-nos dessa imagem de um Deus sofredor que se rebaixa ao encarnar-se e ao ser morto na cruz; também estudamos a ressignificação desse esvaziamento ou despojamento de Jesus de Nazaré para a cultura atual, ainda significativamente marcada pela mentalidade e pelo comportamento patriarcais.

Amparo Novoa P. e Olga Consuelo Vélez C., no artigo "La categoría Kénosis: una lectura desde la perspectiva de género"28 estabelecem pertinentes articulações entre kénosis e teologia de gênero que vão ao encontro da proposta de nosso trabalho. Em primeiro lugar, elas observam a contradição entre estes dois temas na teologia clássica. Entendida como sacrifício e doação, a kénosis foi muitas vezes utilizada pela ideologia sexista para justiçar a opressão das mulheres e promover sua submissão por parte de pregadores e comentaristas bíblicos.

Por essa razão, a teologia das relações de gênero propõe que o significado da kénosis para os homens não deveria ser o mesmo para as mulheres. Os homens, em razão da tendência à autoglorificação, precisam ouvir uma

27 Veja-se os seguintes trabalhos sobre teologia kenótica feminista: COAKLEY, 2002; COAKLEY, 2001; FRASCATILOCHHEAD, 1998; GROENHOUT, 2006; NOVOA P.; VÉLEZ C., 2010; PORCILE, [20-?].

28 NOVOA P.; VÉLEZ C., 2010. 
mensagem de esvaziamento de si próprios e de humildade para receberem a graça de Deus. As mulheres, em virtude de uma identidade construída em torno do autossacrifício necessitam renunciar aos processos de negação de si mesmas. "É incompatível e antievangélico solicitar às mulheres uma atitude de esvaziamento de si mesmas, de negação de seu ser, de sacrifício em função dos outros, no marco de uma mentalidade patriarcal que as invisibiliza e as situa como membros de segunda categoria"29.

Uma das linhas mais interessantes analisadas pela teologia das relações de gênero, segundo as autoras, é a concepção de kénosis como "intercessão". A kénosis é um catalizador crítico para desconstruir a identificação entre Deus e o poder patriarcal. Um dos escopos dessa teologia consiste em ler a kénosis de Jesus como um desafio às estruturas do poder masculino dominante e como suporte da criação de uma nova humanidade marcada pela compaixão e amor mútuo. O maior desafio, porém, é que a própria teologia das relações de gênero seja, ela mesma, kenótica. E para isso, segundo essas pensadoras, ela deve livrar-se da tentação de substituir o poder do patriarcado pelo ginocentrismo. Renunciar ao esvaziamento imposto de si mesmas não significa que as mulheres se tornem as novas agentes da opressão.

Além disso, em uma teologia de gênero kenótica o problema mais relevante é como falar de Deus. Historicamente, essa teologia tentou substituir símbolos masculinos por símbolos femininos. Nossa leitura é que, para desmontar o patriarcado sem sucumbir na armadilha do ginocentrismo, cabe rever a questão da imagem e da linguagem religiosa. E essa revisão passa pelo esforço de imaginar e se referir a Deus a partir da perspectiva da kénosis. Ainda assim, a teologia das relações de gênero precisaria avançar hermeneuticamente para que a compreensão da kénosis não se restrinja a uma leitura que poderia, inclusive, justificar o sofrimento padecido pelas mulheres. O esvaziamento das mulheres não pode ser interpretado como submissão, assim como, no caso dos homens, ele não se limita à mera reprovação de sua prepotência. Essa compreensão hermenêutica precisa ser traduzida em atitudes, em comportamentos, em práticas, em funções sociais em que a igualdade seja algo não apenas formal, mas real.

29 Ibid., p. 174.

Rev. Pistis Prax., Teol. Pastor., Curitiba, v. 10, n. 2, 434-452, maio/ago. 2018 
Novoa e Vélez reforçam que a reflexão sobre a kénosis é um dos caminhos mais profícuos para uma teologia na perspectiva das mulheres. Faz parte da teologia de gênero kenótica a denúncia das estruturas opressoras, assim como a necessidade de resgatar a maneira de existir de Jesus histórico, que concilia a denúncia da opressão e da desigualdade à entrega de si mesmo. Essa maneira de existir que busca libertar-se das estruturas opressoras não inverte os agentes da opressão: que as mulheres assumam o comando do mundo e se convertam em paradigma da humanidade. Pelo contrário, é necessário construir uma liberdade interior e um amor incondicional para "manter a paz diante das dificuldades, o amor em meio ao ódio, a mansidão em meio à beligerância, a autoridade moral daqueles que não se vendem aos meios para conseguir o fim, mas que correm em busca deste a partir da sinceridade do coração" ${ }^{30}$. Significa realizar o seguimento de Jesus por uma renovada experiência de fé, de modo que tenhamos os mesmos sentimentos de Jesus e lutemos pela mudança estrutural das relações humanas que oprimem e nos tornam desiguais.

\section{Considerações finais}

Nesse aspecto, é possível elaborar a releitura do sacrifício cristão a partir de uma teologia da kénosis lida na perspectiva das mulheres. O sacrifício consiste no esvaziamento de si, no amor sem limites. Contudo, ele muitas vezes foi interpretado para as mulheres como aniquilamento social e pessoal. Aniquilamento social, porque elas foram excluídas do exercício de cargos públicos em razão de sua condição de mulheres; aniquilamento pessoal, porque muitas delas foram tolhidas da possibilidade de crescerem profissionalmente em razão de seu confinamento no interior do lar, da perda da capacidade em reconhecer seus desejos próprios, suas reais necessidades e possibilidades. As autoras lembram a ênfase que René Girard atribui à violência inerente aos sacrifícios e a correspondente imagem de Deus que eles proporcionam. De onde sua insistência de que a morte de Jesus foi um

30 NOVOA P.; VÉLEZ C., 2010, p. 180-181. 
crime, não um sacrifício. Ao contrário das religiões que insistem no sacrifício, Deus está do lado da vítima (Jesus) e não do algoz.

Talvez convenha - pelo menos para que sejam compreendidos e não distorcidos - encontrar outra terminologia em lugar da "sacrificial", ou dar-se conta de todo o trabalho de desconstrução que é preciso fazer para recuperar um sentido de sacrifício que se refira ao esforço inerente à condição humana que até mesmo Jesus viveu: "sendo Filho, aprendeu a obedecer" (Heb 5,8) -, o esforço que implica o crescimento no amor e na vida que se dá livre e totalmente por uma efetiva solidariedade e amor pelos demais. [...] Os sacrifícios podem ser impostos como o cumprimento da justiça. Não obstante, o amor não se impõe, senão que é fruto de uma decisão livre e plena. O amor é gratuidade e generosidade que busca ser até o final, até dar a vida ${ }^{31}$.

Depreende-se a dificuldade de falar deste sacrifício em uma cultura patriarcal que tem introjetado, em nós, mulheres, sua compreensão como aniquilação de nosso próprio ser e a designação do amor, como renúncia a nós mesmas. Seria impensável postular uma teologia de gênero kenótica sem essa releitura da kénosis em razão da qual a encarnação e a crucificação de Jesus são consequência de sua liberdade pessoal.

A kénosis supõe uma identidade pessoal autêntica que possa escolher e livremente entregar-se por amor aos demais. $O$ fruto desse abaixamento ou esvaziamento tem que ser a maior vivência da dignidade pessoal, o reconhecimento do valor e sentido do amor que se vive livre, total e inteiramente ${ }^{32}$. Uma teologia das relações de gênero objetiva esvaziar-se das construções culturais de nosso mundo, especialmente aquelas que conduziram a um modo de ser homem e de ser mulher, transformados em aspectos essenciais da identidade. Assim como Jesus "não se apegou" à sua identidade divina, também é atualmente imprescindível não se apegar às construções culturais que organizaram uma sociedade tipicamente patriarcal. Constitui tarefa fundamental, mediante novos imaginários culturais, constituir novas maneiras de ser e de viver em consonância com o desenvolvimento integral e a realização individual e comunitária de homens e mulheres em nosso mundo.

31 Ibid., p. 182.

32 Ibid., p.183. 


\section{Referências}

ARENDT, H. Origens do totalitarismo: Antissemitismo, imperialismo, totalitarismo. Trad. Roberto Raposo. São Paulo: Companhia de Bolso, 2012.

BACON, F. Novum Organum. Livro I. In: BACON, F. Os pensadores. São Paulo: Abril Cultural, 1973. Aforismo III.

BONHÖEFFER, D. Resistência e submissão: cartas e anotações escritas na prisão. Org. Ch. Gremmels, E. Bethge e R. Bethge, coop. I. Tôdt. São Leopoldo: Sinodal/ EST, 2003.

COAKLEY, S. Kenosis and Subversion: On the Repression of the Vulnerability in Christian Feminist Writing. In: COAKLEY, S. (Ed.). Powers and Submissions: Spirituality, Philosophy and Gender. Malden: Blackwell Publishers, 2002. p. 3-39.

COAKLEY, S. Kenosis, Theological Meanings and Gender Connotations. In: POLKINGH, J. The Word of Love: Creation as Kenosis. Grand Rapids: William B. Eerdmans Publishing Co., 2001. p. 192-210.

DESCARTES. Meditações et al. Introd. Gilles-Gaston Granger, trad. J. Guinsburg, Bento Prado Júnior. São Paulo: Abril Cultural, 1973. (Coleção Os Pensadores, v. 15).

DELEUZE, G.; GUATARRI, F. Mille Plateaux. Paris: Minuit, 1980.

FERRY, L. Aprender a viver: filosofia para os novos tempos. Rio de Janeiro: Objetiva, 2007.

FRASCATI-LOCHHEAD, M. Kenosis and Feminist Theology: The Challenge of Gianni Vattimo. New York: State University of New York Press, 1998.

GROENHOUT, R. Kenosis and Feminist Theory. In: EVANS, S. (Ed.). Exploring Kenotic Christology: The Self-Empying of God. Oxford: University Press, 2006. p. 291-312.

HABERMAS, J. El resurgimiento de la religión, un reto para la autocomprensión de la modernidade?. Diánoia, n. 60, 2008.

HEIDEGGER, M. Ser e tempo. Trad. de Fausto Castilho. Editora da Unicamp; Vozes, 2012. 
KANT, I. Fundamentação da metafísica dos costumes. Trad. Paulo Quintela. São Paulo: Abril Cultural, 1973.

KANT, I. Resposta à pergunta: Que é "Esclarecimento"? (Aufklärung). In: KANT, I. Textos seletos. Introdução de Emmanuel Carneiro Leão; tradução de Raimundo Vier (prefácios à Crítica da razão pura) e Floriano de Souza Fernandes (demais textos). 3. Ed. Petrópolis: Vozes, 2005.

NOVOA P., A.; VÉLEZ C., O. C. La categoría kénosis: una lectura desde la perspectiva de género. Theologica. Xaveriana. [online], Bogotá, v. 60, n. 169, p. 159-190, jan./jun. 2010.

PORCILE, M. T. La encarnación del Hijo de Dios en forma masculina y la lógica de la kénosis. RELAT: Revista Electrónica Latinoamericana de Teología, n. 170, [20-?]. Disponível em: <http://www.servicioskoinonia.org/relat/170.htm〉. Acesso em: 08 fev. 2011.

ROLDÁN, A. F. La kénosis de Dios en la interpretación de Gianni Vattimo: hermenéutica después de la Cristiandad. Teología y cultura, año 4, v. 7, 2007.

TAVARES, S. S. Teologia da criação: outro olhar, novas relações. Petrópolis: Vozes, 2010. VATTIMO, G. Après la chrétienté. Paris: Calmann-Lévy, 2004.

WEBER, M. A ética protestante e o espírito do capitalismo (Capitulos II e V). In: Weber. Trad. M. Irene de Q. F. Szmrecsányi, Tamás J. M. K. Szmrecsányi. São Paulo: Abril Cultural, 1974. (Coleção Os Pensadores, v. 37).

Recebido: 21/05/2016

Received: 05/21/2016

Aprovado: 20/07/2018 Approved: 07/20/2018 